\title{
Shadowing Vida Lahey: Bats, Books and Biographical Method
}

\author{
Sue Lovell \\ s.lovell@griffith.edu.au
}

In bumper-to-bumper traffic along the Pacific Motorway at dusk, I edge south past the Logan Road exit towards the Gold Coast. Vehicles moving easily north have already put their headlights on. Flying foxes are massing against the darkening sky. These native megabats will find their way to food using their sharp eyes and sense of smell. As I watch, I am reminded of the microbats of another hemisphere. Those blind bats had prompted Thomas Nagel's famous paper, 'What is it like to be a bat?'

Nagel posed the question, 'What is it like to be a bat?' in 1974. He was examining human perception and experience, asking whether it is possible for one person to really know the mind of another, or to experience another's experiences. The bat example helped Nagel demonstrate the impossibility of understanding experience as having 'any objective character at all' (1974: 448). Ultimately, he argued that just as a human cannot know what it is like to be a bat, there is no way to narrate what it is like to be another person from a third-person, objective perspective. Despite similarities in human sensory and intellectual capacities, what it is like to be a particular person can only be known from a first-person, subjective perspective. Nagel insists, therefore, that 'we are completely unequipped to think about the subjective character of experience without relying on the imagination - without taking up the point of view of the experiential subject' (1974: 449). To gain any insight, in other words, we must acknowledge the loss of objectivity.

Decades later, historians and biographers still interrogate the same philosophical problem: how can we claim accuracy for what we write about another person, or events described by authorities, if nothing is objective? Or, to express the flipside of the coin, how can readers of biography trust that the biographer is not substituting their (mis)recognitions for those of the subject? Clearly, these are not new questions; nor are some of the responses new. In this article, I argue that biographers can develop a rigorous method based on Nagel's recognition that imagination is central to an understanding of the 'experiential subject'. This requires, first, a brief account of one biographer's method of overcoming the conflation of biographer and subject and applying imagination; second, a very particular understanding of 'imagination' via R. G. Collingwood's work; and, finally, the flagging of the relevance of the 'cognitive turn' in narrative theory, which underpins the validity of a more imaginative and embodied approach to biographical research. I will then apply this method to the case of Queensland artist and activist Vida Lahey. 
A biography that maintains clear boundaries between biographer and subject without surrendering imagination is Margaret Somerville's Wildflowering: The life and places of Kathleen McArthur (2004). As the title implies, McArthur was a wildflower artist and environmentalist. Somerville uses the now-familiar feminist strategy of transparently locating herself in the biographical narrative. Her genre challenging text is as much about Somerville and writing biography as it is about McArthur. Because it also prioritises McArthur's work as a conservationist rather than trying to understand her through her private life and relationships, Wildfowering focuses on McArthur's experience of place rather than people.

This example is particularly relevant because my subject is also someone whose life lends itself less to the exploration of personal relationships and more to her work as a cultural activist and artist. Vida Lahey (1882-1968) was one of the few Australian artists who travelled, studied and lived overseas, but she was eager to return to Australia to share what she had discovered with those less mobile or less well funded than herself. Her trips beyond Australia only ever lasted a few years or less and more often than not had very specific objectives: caring for family at war, seeing relatives in New Zealand or studying with particular teachers. She left no personal diaries, and there are relatively few private letters to provide a firstperson perspective on her life. What exists makes for a very broken and erratic record. In such circumstances, an appropriately theorised method for deploying the biographer's imagination becomes necessary. Extrapolation of what does exist, or an expansive interpretation of Lahey's art and known actions, helps to account for character development and emotional continuity. Without careful boundaries around the imaginative act and transparency about when it is applied, the use of imagination can appear to be a case of biographer projection.

Yet the paucity of evidence requires that such a risk be taken. In terms of her art activism, the dominance of formal records hinders understandings of Lahey's cultural experiences of a Brisbane art scene that she helped to shape across the first half of the twentieth century. Together with her sculptor friend, Daphne Mayo, Lahey was instrumental in developing art classes for children in the Queensland Art Gallery, as well as raising funds, advising and purchasing important Australian and international artwork for the Gallery so Queenslanders would come to understand and value art. In relation to her art, a failure of imagination destroys a full recognition of her aesthetic as more complex than the flower paintings for which she is so well remembered.

So how does Somerville activate her imagination in relation to McArthur and avoid conflation with her subject? How does she adopt what I have outlined above as Nagel's 'point of view of the experiential subject'? Somerville takes a camping trip to a wild place McArthur particularly loved and writes a forty-four-page account in the 'biography' about it. The epilogue also tells readers what the biographer learnt from the experience. Somerville would certainly not be the first, and will not be the last, to follow in the footsteps of her subject; indeed, attempting to live from the 'inside' of a subject is a familiar experience to many biographers and historians as they try to capture something intrinsic to their subjects' grasp of the world.

Following a biographical subject in this way is to draw on what R. G. Collingwood calls the historical imagination (1993: 231-49). This idea enriches Nagel's reference to imagination and point of view. As a philosopher of history and aesthetics, Collingwood argued that historical knowledge is: 
$[\mathrm{T}]$ he knowledge of what mind has done in the past, and at the same time it is the redoing of this, the perpetuation of past acts in the present. Its object is therefore not a mere object, something outside the mind which knows it; it is an activity of thought, which can be known only in so far as the knowing mind re-enacts it and knows itself as so doing. To the historian, the activities whose history he is studying are not spectacles to be watched, but experiences to be lived through in his own mind; they are objective, or known to him, only because they are also subjective, or activities of his own (1993: 218).

The appeal of this claim is clearer if we look at it alongside Somerville's pilgrimage into McArthur's landscape. Somerville entered that environment in a highly reflective state, sensitised to her subject's previous engagements with place as a form of spirituality; she tried to perpetuate 'past acts in the present', deploying what Nagle has termed 'taking up the point of view of the experiential subject'. As Collingwood says, though, Somerville has a 'knowing mind', recognising objectively that she is not McArthur. Through her embodied engagement with 'historical knowledge', she self-consciously enters a realm where McArthur's experiences of landscape are not simply an observable 'spectacle', but also 'experiences to be lived through in [her] own mind' subjectively, as 'activities of [her] own'. Somerville re-enacts, in other words, the thoughts of McArthur by placing herself in situ.

Somerville must enter this space using what Collingwood calls the 'historical' or 'a priori imagination' (1993: 231-49). This form of imagination is not dependent on observation (spectacle), nor is it fanciful; it is not mystical, surreal or dreamlike. Rather, the a priori imagination is based on reasonable and logical application of thought: although we cannot perceive it, for example, there is a dark side to the moon, there is an under side to any table (1993: 242); if we look up and see someone walking across the room towards us, turn away and find them at our side, it is reasonable to imagine that they walked across the room. Thus, Collingwood argues, a 're-enacting' historian, thinking the thoughts of the past, can be imaginatively engaged in producing narrative continuity by 'interpolating, between the statements borrowed from ... authorities, other statements implied by them' (1993: 240). These statements form a 'web of imaginative construction stretched between certain fixed points provided by the statements of his authorities' (1993: 242). All that emerges is then contingent on future discoveries, because 'authorities' and 'historical problems' are not 'fixed' permanently but 'remain settled only until he [the historian] or some one [sic] else decides to reopen them' (1993: 244).

This type of body and mind shadowing has frequently been used as a biographical and historical method for gathering data in an intuitive rather than a disciplined way. There is a dismissiveness towards the notion that we are able to 're-enact', in body or in thought, the phenomenological experiences of someone separated from us by time (rather than species), or perhaps of anyone at all. Two more recent developments in narrative theory, however, potentially support the validity of shadowing as a valid biographical method - a means, in other words, for taking up (or running) an other's point of view through one's own 'hardware', through re-enacting. I will simply flag them here and save a closer analysis for a different engagement.

First, Raymond W. Gibbs's research into embodiment and cognition destabilises the legacy of Cartesian dualism. He makes an extended argument that the 
traditional disembodied view of mind is mistaken, because human cognition is fundamentally shaped by embodied experience' (2006: 3). In shadowing McArthur, then, Somerville placed her body in an environment that her subject shared, thus making it much more likely (though not infallibly so) that she can 're-enact' through application of her a priori imagination, the thoughts of her subject. Indeed, the rational nature of the a priori imagination that she should employ becomes the guarantor that she does not lose touch with what is possible or impossible for her subject.

Second, recent narrative theory has increasingly turned to the relationship of mind and body to explore how narrative works experientially and cognitively. Marco Caracciolo (2013) argues that readers of literature experience, or 'simulate', non-real worlds through the first-person perspective. He suggests that 'we simulate only those characters to whose consciousnesses we are given direct access' (2013: 84). Like Nagel, Caracciolo prioritises the first-person perspective; 'direct access' rather than third-person objective narration is the conduit through which imagination flows so that subjectivity may be experienced. The idea that readers are able to access the consciousness of literary characters has traditionally been considered a fiction in itself. Indeed, literature depends upon this idea so readers willingly suspend disbelief and enter the world of the characters, accepting it as real, identifying with characters and sharing their emotional lives.

Caracciolo continues: 'But since these consciousnesses are simulated or enacted by readers, the experiences involved are, after all, the reader's own' (2013: 84, emphasis added). This time, like Collingwood, Caracciolo maintains that the outcome of reading is the lodging or embodiment of experience in the body of the reader. This can be thought of as an experiential relay from text to reader. No one thinks anything of it simply because the authoritative status of fiction is very different from that of biography and history, which are both expected to deliver 'truth' rather than a truth effect.

What follows is a demonstration of the use of a priori imagination to enable biographers to tap into the same mechanism used by fiction, but in a way that does not devalue the status of biographical narrative. That is, I shall apply a biographer's a priori imagination and experience re-enactment without conflating subject and biographer, and without imagination becoming synonymous with fabrication. The method will be applied with the goal of developing an understanding of Lahey's response to World War II, even though there are very few records of that response from her first-person perspective. Recalling Collingwood, one provisional 'fixed point' in terms of 'authorities' is existing knowledge of her response to World War I. Then, she was sent to London by the extended family because eighteen young men in that generation were fighting (Lahey, S. 2003: 261-70). There are some letters home, replicated in her niece's family history (Lahey, S. 2003); a long period of recuperation in Tasmania staying with her friend, artist Mildred Lovett; and there is also the commemorative painting Rejoicing and remembrance, which poignantly captured her deep sorrow and relief (Lovell 2006: 13, 20-1).

When war returned, the situation was very different: she was in Australia, mostly Brisbane, and no one of her generation was in the war. It is premature, however, to assume that she had no strong feelings. The same desire to do her part meant that Lahey managed to get her name on a list from which war artists would be selected - though she was never chosen ('Appointment' 1942, n.p.). Since the ubiquitous 
nature of daily life means that a physical shadowing such as that of McArthur by Somerville is impossible, I am going to intellectually 'shadow' Vida to see whether I can apply a priori imagination to the task of understanding her response to another war. I begin before the war to establish an aspect of her character: how she responded to change and instability in the art world as the challenge of modernism led to conflicts about the content, form and function of art in society.

Even a brief look at Lahey's art indicates a focus on flowers, but she also painted cityscapes, particular buildings, water scenes, landscapes, camping, boating, workers and workplaces. Messages or statements, if there are such in her work, are subtle and subsumed by colour, form and beauty — itself a statement that she most valued a vibrant engagement with life based on harmony and balance in ordinary daily living. Art and nature (1934) is different, however. Art and nature has been called Lahey's “"manifesto” statement for modernism in Queensland' (Cooke 1995: 50), and linked to public debate in the Courier-Mail in April 1933. In that debate, modernism - what fellow artist Roy Parkinson called 'the ultra modern in art' (in Cooke 1995: 50) - is called to account. Art and nature is a visual rendition of Lahey's position in that debate rather than a pro-modernist statement. A still-life watercolour, it showcases a jug of flowers, a book and a classic bas-relief of a woman's head with hair streaming behind sculpted by Daphne Mayo.

Art and nature employs the "white on white" technique used ... by Manet and other French painters' (MacAulay 1989: 73), so the slightly off-centre jug of orange Mexican sunflowers in a pale setting is vibrant. This impression is reinforced by the way the light seems to radiate from within. The handle of the jug, angled towards the viewer, implies a hand just withdrawn. (My a priori imagination immediately inserts Vida stepping backwards to contemplate the effect, so the setting up of the still life merges with the painting it has become; I stand to one side and behind her, unseen. She sees the orange of the sunflowers echoed in the colour of the book placed slightly left of the jug. She gives the book a small nudge further to the left. I can't see if she is smiling, but now I can see the book bears the single word: MATISSE. I fade out.)

The book is a clearer connection to the French than the white on white technique, and even more overt than the placing of jug and book on a smooth part of a pale tablecloth that, from centre front of the painting, is rumpled and puckered in a style said to be reminiscent of Cezanne (Cooke 1995: 51). The raised folds curve right like a miniature mountain range ... (an image flashes, surely we hold it in common - the Border Ranges Vida and I see from Tamborine - we stand side by side, looking west across the valley.) The eye follows the folds around the jug towards the back of the painting, meeting the hair of the sculpted woman, giving way to her hand, half-hidden behind the hair.

The curve of the cloth is maintained by the upper hairline, though the flow and therefore the direction of the gaze - is reversed because the hair streams left to right, across the hand, back to the folds of the cloth, embracing the bright orange sunflowers, resting the eye there again. The jug and flowers dominate through position, colour, line and form. The book is present but offset; the face of the woman, with eyes apparently closed, is turned towards the book, but is clearly disengaged. As Glenn Cooke writes, Lahey 'chose to acknowledge her awareness of Matisse by depicting a book with his name thus placing the connection at one remove' (1995: 52, original italics). 
Lahey's Art and nature represents a politics of art that argues for an open-minded and exploratory process responsive to the conditions of life, informed but never dominated by what surrounds it. Her own work, governed by this principle, was 'modern in its ideas', while still able to be praised for its 'sound draughtsmanship and clear, live colours' ('Women artists' 1935: 18). The a priori imagination can, however, interpolate and extrapolate beyond the statement of what is represented to suggest first Vida's progressive attitude and second that she took the longer view, looking both to the past and the future. Thus, the painting foregrounds the role of nature and acknowledges the underpinning of all art by the classical traditions that have preceded its modern form, but accepts other organising principles in an everchanging world. An a priori imagination can also give this interpretation texture by linking to more 'authorities' than those in the art world.

It may suggest the items in the painting represent ideas or acts intrinsic to Lahey's personality. Her niece, Shirley Lahey, for example, owned a deep red vase of Vida's from the studio opposite the Customs House, where it was on a shelf 'with all manner of things'. These objects were painted by Vida and were available to those, like her niece, who had art lessons from her. Shirley chose to draw the vase one day, and acquired it because 'jugs or vases of Vida's that appeared in paintings were given to people, [or] went to people with the painting' (Lahey, S. 2008). Shirley Lahey therefore becomes a (still contingent) authority for recognition of Vida's generosity. Sunflowers, which turn their faces to the sun as it moves east to west, may be symbolic of the homage that Vida paid to nature (in my mind, an image appears, Vida taking from the shelf a book on the symbolism of flowers). The French allusions could be reminiscent of her 'carefree' (Lahey in MacAulay 1989: 87) sojourn in Paris. The book may represent not only the challenge that modernism presented to traditional, representational art because of the name upon it, but the value of reading, education and that informed, progressive outlook that embraced any engagement with art. She is on record as saying, during the debate, that 'it is good that the theories should be tried out and new interpretations of life be given, even if they do not coincide with our own' (Lahey 1933: 28).

Lahey may even stand as an authority on herself, as what were meant to be private communications for an audience of one are revealed, examined and linked to public statements. She notes in a letter to Mayo, for example, that:

My task with the catalogue has driven me to [Bernard Smith's 1945] 'Taste, place and tradition', which I am ashamed to say I condemned on its first appearance after a quick look through its pages. I am now reading it and think it quite good. It is a blow to one's self-esteem to find one has been so unfair - not to mention mentally lazy as to ignorantly condemn (Mayo Archive, 17 October).

Although it is clear (in erratically surviving letters in Mayo's archive) that Daphne, Vida and their friends read one another's books, the allusions to them are very slight and often unclear. Nevertheless, one confirms that Vida engaged with art critics and historians despite difficulties. On retreating to Tamborine one New Year, she writes:

I brought Read with me to have another [illegible, but possibly grind]. He's terribly depressing. The sun gets up at an unearthly hour here. And as there are no blinds, we have $\mathrm{m}$. tea [sic] about 5.30 and then retire to bed to read until 
breakfast time ... I am trying to do something (groan) but this subject matter is terribly difficult (Mayo Archive, Tamborine Mt. Friday).

She refers to Read again in a letter dated 9 March 1953 (aged 71), saying, 'Darling [illegible] tell me not to harass my brain with Read — but I like doing so, I only wish I were not so close to the doddering stage, as for it not to matter.' It is impossible from either of these entries to know whether she is reading Art and society (1936), Education through art (1943), or The philosophy of modern art (1952). In fact, what the a priori imagination seizes is not so much the details of what is read as the image of Vida curled into bed, patiently, then stubbornly, turning the pages, shaking her head, but fully believing it was her duty to herself to become informed. What she's really enjoying, though, is the call of whip birds, and the random, lazy thoughts of breakfast that weave themselves between the lines. Try as it might, though, the a priori imagination has insufficient evidence to assume that the 'we' who rise at 5.30 means that Vida is sharing her bed or even her room with another woman; even if she were, the further extrapolation of that sharing into a sexual relationship would be inappropriate without a much more substantial piece of evidence from which to hang the web of inference. To do so is to resort to precisely the form of imagination that Collingwood rejects in favour of one that is a priori.

Moving into the war years, I want to now use another 'authority' to see whether the facts and the imaginings I have so far developed around the issue of Lahey's politics can help gain perspective on her response to World War II. This time, it is something of Vida's own making: the transcript of a lecture delivered at some unknown point at the University of Queensland in the early 1940s. ${ }^{1}$ The inclusivity and long view interpolated from Art and nature are writ much larger here, thus supporting the imaginative reading of them.

Reading the lecture in the silence of the Fryer Library over two-thirds of a century after she first delivered it does nothing to dampen the ardour of Lahey's 'voice'. (Imagination insists the urgency is prompted by the horror of war and despair over human nature - an image of Virginia Woolf appears, loading stones into her pockets.) What was previously an inclusive desire to learn is now a passion to communicate, to teach the way to recovery. 'Art,' she asserts, is 'an international language - a language that knows no barrier of place or time, and by which spirit speaks to spirit, and century to century' (Lahey $194^{*}: 2$ ). Through the 'language' of art, people can be brought together. Cezanne appears again, working 'symbolically' to produce not 'portraits of persons or places, but portraits in which the violence or some other aspect of our times is suggested' (194*: 4). The increasingly 'mechanical', 'regimented and uniform' approach to life was, she claimed, turning people into 'mere cogs in the soulless routine of business' (194*: 3). (An incomplete quote from Herbert Read drifts by — something about individuals and a mass, yes — thank you Google: 'If the individual is a unit in a corporate mass, his life is not merely brutish and short, but dull and mechanical'.) Technology ('war technology', 'technology for destruction') was not liberating humankind: it was oppressive in its ability to separate people from nature and from art.

These views are expressed in Art for all as a response to the American architectural critic in The New Yorker, Lewis Mumford, especially his Technics and civilisation (1938), the first of four books in the Renewal of life series. Mumford still held a relatively optimistic view of technology in 1938, but Lahey was less 
accommodating in Art for all. What is visible in her appeal to art as a peacebuilding tool, what she most shared with Mumford (and Read, perhaps), was a romantic commitment to 'organicism' understood as 'a sustained vindication of a single view of reality' (Marx n.d.: 5-6). For Lahey, this 'single view' was the reintegration of art and life. 'Where lies the blame?' she demands. 'It is the fault of the age in which we live, plus the unbalanced education we have all received' (194*: 4).

Lahey believed integrating art and life, as both fine art and understanding of design-oriented principles, was the task of a balanced education. Her mother was a teacher's assistant before marriage, her father an autodidact. She had the best private school education that money could buy; her art training occurred interstate and internationally. Lahey placed her hope for the future in education as a long-term answer: 'Through education the orientation of our civilisation could be changed,' she declared in Art for All; and, because '[a]s the twig is bent, so is the bough inclined', educating children was the place to begin. This was 'not to turn every child into an artist, but to develop in each child the capacity to enjoy a new world of delight that is free and could be open to us all if our senses were trained as much as our intellects' (194*: 5). Even the tone of Lahey's rhetoric is reminiscent of Mumford, who later wrote in Values for survival (1946):

If we are to create balanced human beings, capable of entering into world-wide co-operation with all other men of good will - and that is the supreme task of our generation, and the foundation of all its other potential achievements - we must give as much weight to the arousal of the emotions and to the expression of moral and esthetic values as we now give to science, to invention, to practical organization. One without the other is impotent (in Halton: n.d.).

What was at stake for social activists like Lahey was their belief in the 'goodness' of human nature - its ability to survive. Through intervention by those who had long-term vision - both to the past and the future - society could be returned to stability and freedom, without sacrificing self-governance to authoritarianism. Lahey wanted people - particularly children - to be thinking individuals:

I would like to make it clear that by increased art education I do not mean merely more of the old fashioned type of drawing lessons that we sparsely received ourselves, but art education along modern lines, which makes enjoyment a spur to effort and aims at drawing out imaginative and constructive ideas rather than merely copying objects in a mechanical manner (Lahey 194*: 6).

This approach followed the practices of other progressive children's art educators such as Franz Cizek in Vienna, or Arthur Lismer in Toronto Canada (Lovell 2010: 281-3), the Sydney artist Rah Fizelle and Margaret Rees (McKay 1981: 170). The classes were established in the Art Gallery, like those in Toronto, in 1941 after many years of activism led by Lahey and Daphne Mayo through the Queensland Art Fund (QAF) and other local art groups.

Lahey's focused energy found an institutional outlet that was well placed to better inform the public about the value of art. The classes for children were all a part of this, and the Carnegie Corporation of New York was approached for assistance in their establishment in 1936. Rather than support children's classes, however, it donated two hundred books, 2000 photographs, reproductions of paintings and 
other art-related material as the nucleus of what became the QAF Reference Library, with Vida as its first custodian (MacAulay 1989a: 22-31; Lovell 2010). ${ }^{2}$

Just as Lahey exhausted herself in World War I in London, during World War II she became deeply embroiled in home-based battles. This time, however, it was broader and more nebulous, nothing less than to address the ills of the world through ensuring the widespread understanding of art as a language that developed a capacity to communicate emotions, develop the imagination and seek constructive solutions. Children's art and the QAF Art Reference Library were instrumental in fulfilling this purpose. In going to the records of the QAF, then, would it be possible to gain insight through further 'reference points' relevant to the library's first custodian?

The QAF minutes contained circulars encouraging people to (re)join the Library for $£ 1 / 1 / 0$, reminding them:

It is the only library in Australia open to the public where large-scale photographs and pictures can be studied in association with the books which describe them. 2000 photographs, 40 pictures, and 500 books dealing with Architecture, Sculpture, Painting and Crafts from $3000 \mathrm{BC}$ to the present may be consulted (QAF Circulars).

The increase in books from the Carnegie Foundation's original donation of two hundred is clear, and records show that Vida was charged with increasing them and maintaining them and the premises. On 8 December 1937, she was 'authorised to spend $£ 5$ on new books on such subjects as watercolour and landscape painting or of a particular value in interesting the general public and children'; on 16 June 1939, 'such very good use had been made of the library' that more books would be sought from Carnegie on 'English art and text books, oil and watercolours, and arts and crafts generally. It was decided to 'leave the choice of books to Ms Lahey and Professor Richards'; 1 March 1940 notes 'Acceptance of a gift of books (El Greco and Account of French Painting from Mssrs RF Steele and RJ Pring'; on 4 October 1940, it was 'resolved that a copy of Studio be purchased regularly out of funds, for the use of the Library'; on 10 March 1941, 'Miss Lahey moved that a delegate be sent to represent the Art Library at the Education Conference to be held in Brisbane shortly' - Miss Lahey was nominated.

Sometimes books on loan had to be returned; an undated circular notes that 'Professor Duhig desired the return of a collection of books which he had generously lent us for a space of four years ... a promise given to Miss Mayo by Mrs [sic] Margaret Preston to bequeath a valuable collection of books to the Library should be recorded'. When books went missing, the custodian reported it to the QAF Committee and the minutes of 22 September 1939, for example, duly noted that the C.I. [Criminal Investigation] Branch had been notified immediately and had done all they could but the book had not been recovered'. The power of the custodian was such that no book entered the shelves of the Art Reference Library without her input. On 17 March 1937, several books were donated as gifts and the minutes (kept at that time by Vida) record that, 'The Hon[orary] Sec[retary] reported that the two former would have only limited appeal, but if stored in the back room for reference, if desired, she would recommend their acceptance; the third would be of use in the Library'. 
These records provide some insight into Lahey's active and discerning custodial role. It is difficult not to think of The studio (1950) when reading the entry for subscription to it. Like Art and nature, it features a book - or, in this case, a journal - placed behind flowers, attesting to the retention of the politics discussed earlier. The letters, though, reveal the strain of this work in addition to art classes, commitments to her family and that of Daphne Mayo, and trying to do her own work. She writes that it all left her feeling 'drained dry' (Mayo Archive, St Lucia Tuesday Night). The most interesting thing in the QAF records, however, was a list of books donated or lent to the library by Lahey (among others).

Feeling much more like Somerville on the heels of McArthur (even my body responding to the idea of being able to discern something personal about my subject), I quickly scanned the list. Would Vida donate outright books she no longer valued and only lend books on colour, children's education, impressionists, modernity, art gallery catalogues from her trips to Europe? Mumford's name leapt from the page and seemed to confirm the idea instantly: Technics and civilization - lent by Vida Lahey; The culture of cities by Mumford, bought for the library; Herbert Read's Education through art, bought for the library; as was Child art by Cizek's admirer, Wilhelm Viola. It quickly became apparent, though, that Vida had a sorting system I could not 'imagine' without studying the books.

She lent some catalogues but donated others, and some appeared in both columns; she lent the autobiography of Frank Lloyd Wright, but donated J. S. Macdonald's biography, The art and life of G. W. Lambert; she donated seven publications related to Australian art and artists, and lent only one, the Australian art annual 1937; she donated ten introductory books on art and lent three. Two categories stood out: five books on colour and four books on architecture, all of them loaned. Three other books Children as artists, Marionettes and Animals in Chinese art were donated, but had to be sought from the 'custodian' so their whereabouts were doubly safe, yet three books on various forms of Oriental art were only lent. On this note, my experiment in intellectually 'shadowing' Vida Lahey draws to a close.

Since the moment I saw those flying foxes crossing the Motorway and placed Nagel's question alongside Collingwood's a priori imagining, one thing that has become clear is that imagination, once released, sneaks about and inserts itself at unexpected moments into the process of writing biographical narrative. It has the capacity to leap to inappropriate, entirely speculative commentary; it may also transport researchers into a 're-enacting' moment that is startling in its embodied intensity or the clarity of it recognitions. If mind and body are not separate, as the cognitive narrative theorists suggest, then it is not so surprising that where the mind ventures, the body follows. I did not expect to be standing behind Vida, watching her move the book a little more to the left. Nor did I expect to see her so clearly struggling with Read as the whip birds called.

Because the imagination can easily escape the bounds of conventional research, it must be pulled severely into line by the a priori. For a biography to have any authoritative standing, there must be transparent failures of imagination: an inability to know what Vida was thinking as she decided which books to lend and which to donate; no legitimate placing of a sexual partner alongside her at Tamborine. Perhaps I never will be able to establish or imagine these moments. Perhaps, however, I can track down more books, more evidence to feed into the process of 
gaining insight. Something else that emerges clearly — and the reason, perhaps, that biographical research is so addictive for some - is that the more that can be factually (even though provisionally) discovered about a subject, the more likely it is that the a priori imagination will thrive accurately. A lot of what initially 'feels' imaginative becomes, as the treatment of Art and nature potentially shows, a more reasonable and logical imagining.

So, how did Vida Lahey respond to World War II? She responded as she had to respond as a creative, thinking person: with the kind of deep concern about the future of humanity that came to characterise the nuclear age. She took what she knew best, and, as an actively engaged, diligent, middle-class citizen, she used all that she had at her disposal to counter the loss of hope and the despair that people who had lived through World War I must surely have felt throughout World War II —and, unlike Virginia Woolf, Vida survived.

\section{Endnotes}

1 This has been referred to as the second Duhig Lecture, but the memorial lectures in honour of Sir James Duhig, Brisbane's long-serving Catholic Archbishop, started in 1978, so there is some confusion that currently remains a mystery.

2 I won't rehearse this history, but for those who are interested, there is a detailed explanation of the struggle involved in getting art classes for children in these two sources and deeper contextualising of the comments here in Lovell (2010).

\section{References}

'Appointment of Miss Vida Lahey as official war artist' 1942. Extract from the Minutes of Art Committee held in Sydney, 12 January. Canberra: AWM 93, File No. 50/4/2/88, Australian War Memorial.

Caracciolo Marco 2013. 'Blind reading: Towards an enactivist theory of the reader's imagination', in Lars Bernaerts, Dirk de Geest, Luc Herman and Bart Vervaeck (eds), Stories and minds: Cognitive approaches to literary narrative. Lincoln, NE: University of Nebraska Press, pp. 81-105.

Cooke Glenn R. 1995. 'Art and nature: Flower painting as a vehicle for modernism in the work of Vida Lahey', Queensland Review 2(1), 42-52.

Collingwood R. G. 1946. The idea of history. Revised edition. Ed. Jan van der Dussen. Oxford: Clarendon Press, 1993.

Gibbs Raymond W. Jr 2006. Embodiment and cognitive science. Cambridge: Cambridge University Press.

Halton Eugene, n.d. 'A brief biography of Lewis Mumford (1895-1990)'. Accessed 28 September 2013, http://www.nd.edu/ ehalton/mumfordbio.html.

Lahey Shirley 2003. The Laheys: Pioneer settlers and sawmillers. Brisbane: self published.

Lahey Shirley 2008. Conversation with Sue Lovell. 2 February, Taringa. Notes with author.

Lahey Vida 1933. 'Letters to the editor'. Brisbane Courier, 9 June 1933, 21.

Lahey Vida 194* [sic] Vida Lahey, Art for all. Brisbane: Queensland National Art Gallery for the Combined Art Committee of Queensland.

Lovell Sue 2006. “'Dew to the soul”: One Australian artist's response to war', Journal of Australian Studies 30: 88, 13-25. 
Lovell Sue 2010, 'Vida Lahey's progressive activism for children's art education', Australian Historical Studies 41(3), 269-85.

MacAulay Bettina 1989a. Songs of colour: The art of Vida Lahey. Brisbane: Queensland Art Gallery.

MacAulay Bettina 1989b. Supplement to songs of colour: The art of Vida Lahey, works located to 1989. Brisbane: Queensland Art Gallery.

McKay Judith 1981. 'Daphne Mayo, sculptor'. Masters thesis, University of Sydney.

Marx Leo n.d. 'Prophet of organicism'. Working Paper No. 2. Boston: MIT.

Mayo Archive. 'Letter from Vida Lahey to Daphne Mayo, 17th October', Mayo Archive, UQFL119 Box 27 Folder A: Correspondence Inward Undated, Fryer Library, Queensland University.

Mayo Archive. 'Tamborine Mt Friday', Mayo Archive UQFL119 Box 28, Folder: Incoming Undated, Fryer Library, University of Queensland.

Mayo Archive. 'St Lucia Rd, St Lucia, March 9th 1953', Mayo Archive, UQFL119 Box 28, Folder: Correspondence Inwards 1950s, Fryer Library, University of Queensland.

Mayo Archive. 'St Lucia Rd, St Lucia Tues Night', Mayo Archive, UQFL119 Box 27, Folder A: Correspondence Inwards Undated, Fryer Library, University of Queensland.

Nagel Thomas 1974, 'What is it like to be a bat?' The Philosophical Review 83(4): 435-50.

Queensland Art Fund 1939. 'Art Library records: List of donations and books on loan, March 31st 1939', Box 5, Folder: Queensland Art Reference Library. Fryer Library, University of Queensland.

Somerville Margaret 2004. Wildflowering: The life and places of Kathleen McArthur. Brisbane: University of Queensland Press.

'Women artists' 1935. 'Women's world', Courier-Mail, 23 September 1935, 18. 